\title{
Intraoperative Priapism in Two Elderly Nigerian Men Undergoing TURP, A Rare Complication of Spinal Anesthesia-Case Series
}

\author{
Adigun TA ${ }^{1 *}$, Sotunmbi $\mathrm{PT}^{1}$ and Shittu $\mathrm{OB}^{2}$ \\ ${ }^{1}$ Department of Anesthesia, University of Ibadan and University College Hospital, Nigeria \\ ${ }^{2}$ Department of Surgery, University of Ibadan and University College Hospital, Nigeria
}

Submission: August 05, 2019; Published: August 22, 2019

*Corresponding author: Adigun TA, Department of Anaesthesia, College of Medicine, University of Ibadan and University College Hospital Ibadan, Nigeria

\section{Abstract}

Background: Priapism is a persistent penile erection unrelated to sexual activity. The etiology may be primary, secondary or idiopathic. However, priapism following spinal anesthesia is not common but a rare occurrence.

Objective: To report 2 cases of intraoperative priapism in two Nigerian men scheduled for transurethral resection of the prostate under spinal anesthesia.

Methods: Two Nigerian men, one aged 62 years, hypertensive with benign prostate hypertrophy and the other 63 years, hypertensive and diabetic patient with benign prostate hypertrophy scheduled for TURP under spinal anesthesia.

Results: They both developed intraoperative priapism 30 minutes after spinal anesthesia, they were sedated with pentazocine $30 \mathrm{mg}$ and promethazine $25 \mathrm{mg}$ without improvement in detumescence, their surgeries were abandoned, and priapism resolved after the spinal anesthesia had worn off.

Conclusion: Priapism may present in patients that had spinal anesthesia for urological procedures. Sedation may be useful, but the priapism usually resolves after the spinal anesthesia wears has off.

Keywords: Priapism; Spinal anesthesia; Rare complication

\section{Introduction}

Priapism is a persistent penile erection unrelated to sexual activity caused by disturbances in the mechanism controlling penile detumescence and the maintenance of penile flaccidity. It is a urological emergency and if left untreated it may result in impotence. There are many causes of priapism but priapism following regional or general anesthesia is rare, with incidence $0.1-1 \%[1,2]$. When it occurs during urological procedures it may cause a delay or cancellation of the proposed surgery.

We present two cases of intraoperative priapism in patients with Benign Prostate Hyperplasia (BPH) scheduled for transurethral resection of the prostate (TURP). They both had spinal anesthesia for the procedure and developed prolonged penile erection without ability to continue with the procedure as the cystoscope and resectoscope sheaths could not be inserted into the urethra. Intravenous pentazocine $30 \mathrm{mg}$ and promethazine $25 \mathrm{mg}$ were given for sedation and surgeries were postponed. The priapism resolved after the spinal anesthesia worn off and both patients had no residual penile dysfunction.

\section{Case 1}

In the year 2007, Mr. 0. J. 0, a 62-year-old gentleman was admitted with symptoms suggestive of bladder outlet obstruction secondary to BPH and scheduled for TURP. Preoperative review revealed that he was a known hypertensive for 5 years on amlodipine $5 \mathrm{mg}$ daily. He was not a known diabetic or asthmatic patient. No history suggestive of respiratory or cardiac disease. No previous surgery or blood transfusion history in the past. No known drug allergy history.

General examination revealed an elderly man, not pale, anicteric, acyanosed, no peripheral oedema. Chest examination showed good air entry bilaterally with vesicular breath sounds. Respiratory rate was 14 cycles/minute. The cardiovascular 
system revealed pulse rate of 88 beats/minute, blood pressure 130/80 mmHg, heart sounds 1 and 2 were heard.

Investigation done were packed cellvolume of $41 \%$, electrolytes (Sodium 144, Potassium 3.5, Chloride 99 and Bicarbonate 25) and Electrocardiograph was of normal sinus rhythm. The patient was assigned America Society of Anesthesiologist (ASA) class 2. Consent was taken for surgery and anesthesia.

He had spinal anesthesia in the sitting positing at L3/4 after preloading and obtaining baseline vital signs. Heavy Bupivacaine $0.5 \% 3.5 \mathrm{mls}$ was injected into the subarachnoid space after a free flow of cerebrospinal fluid. He was placed supine afterwards, height of block was at T6 and complete block was achieved. Blood pressure ranged between $137 / 86 \mathrm{mmHg}$ to $117 / 78 \mathrm{mmHg}$, pulse was $80-88 /$ minutes and oxygen saturation was $95-99 \%$.

He was later placed in lithotomy position for the procedure with the patient prepped and draped. An initial tumescence (full) but soft and drooping penis gradually became fully erect hard and forming an acute angle with the anterior abdominal wall. In this position the endoscope could not be inserted into the urethra beyond the penile urethra. The scope was removed as the surgery could not continue. The patient was given pentazocine $30 \mathrm{mg}$ and promethazine $25 \mathrm{mg}$ for sedation.

The surgery was delayed for 1 hour without detumescence and the surgery was postponed for a week and patient was transferred to the recovery room and the priapism resolved after the spinal anesthesia worn off.

\section{Case 2}

In the year 2017, Mr. J. A, a 63 year old man with symptomatic bladder outlet obstruction from BPH was scheduled for TURP. Preoperatively, he was a known hypertensive of 5 years duration on lisinopril $5 \mathrm{mg}$ daily and also a diabetic patient on metformine $250 \mathrm{mg}$ twice daily. He was compliant with his medication with his blood pressure and blood sugar well controlled. Patient had no previous surgery or blood transfusion and no known drug allergy.

Examination showed a middle aged man, not pale, anicteric and acyanosed. No abnormality was detected in the respiratory system. Cardiovascular examination showed a pulse rate of 80 beats/minutes, blood pressure $140 / 80 \mathrm{~mm} \mathrm{Hg}$, heart sounds 1 and 2 were heard no murmur heard.

Laboratory results showed a packed cell volume of $45 \%$, electrolytes were within normal limits, fasting blood sugar was $80 \mathrm{mg} / \mathrm{dl}$, electrocardiograph was of sinus rhythm.

He was assigned ASA classification 2. He had spinal anesthesia under sterile procedure with $3.5 \mathrm{mls}$ of heavy Bupivacaine injected into the subarachnoid space. Standard monitoring was with noninvasive blood pressure and pulse oximeter every 5 minutes. Patient did not develop any hypotension.

He was positioned in the lithotomy position and prepped and draped. However, 30 minutes after subarachnoid block he developed priapism and the surgery could not be continued as the subcutaneous veins of the penile skin engorged. The scope could not be passed beyond the penile urethral and the surgery could not continue. The patient was given pentazocine $30 \mathrm{mg}$ and promethazine $25 \mathrm{mg}$ for sedation.

The surgery was delayed for 1 hour without detumescence and the surgery was postponed for a week and patient was transferred to the recovery room and the priapism resolved after the spinal anesthesia had worn off.

\section{Case 3}

The above patient presented 3 months after, had spinal anesthesia but still developed priapism, patient had open prostatectomy and the procedure was uneventful and the priapism worn off in the recovery room.

\section{Discussion}

Priapism is defined as a persistent erection unaccompanied by sexual excitement. The incidence of priapism following spinal or general anesthesia is $0.1-1 \%$ as documented in the literature [1]. It is a urological emergency and if priapism is sustained for more than 4 hours, it may result in oedema, increased risk of abrasion, tissue dryness and necrosis of the penis, prognosis depends on the type of priapism and the time before the therapeutic intervention [3].

Autonomic imbalance between the sympathetic and parasympathetic nervous system is generally considered to be the cause of intraoperative erection. Priapism can occur during any mode of anesthesia. Psychogenic and reflex erection may occur during the early stages of spinal anesthesia when the pathways are still incompletely blocked, another possible explanation is incomplete blockade of sacral segments of the nerve roots [4]. In addition, local anesthetic agents may depress cortical centre in the brain that normally inhibits the penile erection in the conscious individual, thereby enhance erectile response to tactile stimulus [5].

Causes of priapism may be primary, secondary or idiopathic. Earlier report by Adeyokunnu et al. [6] in 1981 and recently by Ugumba et al. [7] in 2016 identified sickle cell disease as the commonest cause of priapism in Nigeria. Priapism as a complication of spinal or general anesthesia is uncommon but similar reports have been documented by authors in the literature [8-10].

Natarajan et al8 reported a case of introperative priapism in a 59 years old man admitted for TURP, patient had spinal anesthesia and was treated with glycopyrrolate. Ravindaran et al. [9] reported 2 cases of intraoperative priapism and patient responded to ketamine $0.5 \mathrm{mg} / \mathrm{kg}$ and $1.5 \mathrm{mg} / \mathrm{kg}$ of physostigmine with flaccidity occurring within 90-110 minutes. Gale et al. [10] treated intraoperative priapism that occurred during general anesthesia with ketamine $1 \mathrm{mg} / \mathrm{kg}$ and recorded flaccidity within 25 minutes, Benzon et al. [11] however recorded flaccidity after two hours 
with 100-150mg of ketamine and hypertension was recorded in the patients [12]. Honorio et al. [13] also reported intraoperative priapism in 2 patients that had spinal anesthesia for TURP, but patients did not respond satisfactory to ketamine. Although, the most frequent used medication to treat intraoperative priapism is ketamine, however it does not work always. Moloney et al used chlorpromazine to treat intraoperative priapism in patients that had epidural anesthesia and noticed a transient penile flaccidity [12].

The use of Ketamine was considered inappropriate and possibly dangerous in our patients being known hypertensives and elderly. We used promethazine and pentazocine for sedation in our patients although immediate detumescence was not noticed but complete flaccidity was noted in the recovery room as the spinal anesthesia wore off. Conversion to general anesthesia was considered by some authors with good effect especially to avoid the delay in surgery and postponement of surgery that occurred in our patients.

Terbutaline, a beta 2 adrenoreceptor agonist has been used successfully however, it may cause tachycardia, pulmonary oedema and hypokalemia and should be used with caution [14].

Intracorporeal injection of alpha-adrenergic agonist such as epinephrine, phenylephrine, metaraminol and etilephrine [15] are other known measures to treat priapism however, the risk of systemic uptake of these medication with the possibility of hypertension and myocardial or cerebrovascular accident in our patients make their use dangerous. Administration of such drugs may be considered in young patients without the risk of vascular compromise.

Treatment options for all types of priapism are initially conservatives with medications but surgical shunts are done when these methods fail [16]. The aim of the surgical treatment is to provide shunt between corpus carvenosum and glans penis, corpus spongiosum or vein so that the obstructed veno-occlusive mechanism is bypassed.

\section{Conclusion}

Patients presenting for urological surgery under spinal anesthesia may present with intraoperative priapism. Patients should be sedated, and the priapism usually resolve after the spinal anesthesia wears off.

\section{References}

1. Banos JE, Bosch F, Farre M (1989) Drug induced Priapism. its aetiology, incidence and treatment. Med Toxiolo Adverse Drug Exp 4(1): 46-58.

2. Van Arsdalen KN, Chen JW, Smith MJ (1983) Penile erections complicating transurethral surgery. J Urol 129(2): 374-376.

3. Bosch RJ, Benard F, Aboseif SR, Stief CG, Lue TF, et al. (1991) Penile detumescence, characterization of three phases. J Urol 146(3): 867871.

4. Bors I, Coman AI (1981) Neurological distribution of sexual dysfunction with special references in 529 patients with spinal cord injury. Urol Survey 10: 191-195.

5. Wong YJ, Hong J (2008) Penile erection during Transurethral surgerycase report and review of the literature. Anesth Pain Med 3: 154-156.

6. Adeyokunnu AA, Lawani JO, Nkposong EO (1981) Priapism complicating sickle cell disease in Nigeria children. Ann Trop Paediatr 1(3): 143-147.

7. Ugwumba FO, Ekwedigwe HC, Echetabu KN, Okoh AD, Nnabugwu I, et al. (2016) Ischemic priapism in south east Nigeria, presentation, management, challenges and aftermath issues. Niger J Clin Prac 19(2): 207-211.

8. Natarajan P, Remadevi R, Rao PB, Ramachandra TR (2012) Priapism following spinal Anaesthesia in urological procedures. Anaesthesia, Pain and intensive care 16(1): 47-50.

9. Ravindran RS, Dryden GE, Somerville GM (1987) Treatment of priapism with ketamine and physostigmine. Anesth Analg 829-36.

10. Gale AS. (1972) Ketamine prevention of penile tumescence. JAMA 219: 1629.

11. Benzon HT, Leventhal JB, Ovassapian A (1983) Ketamine treatment of penile erection in the operating room. Anesth Analg 62(4): 457-458.

12. Maloney PJ, Elliot GB, Johnson HW (1975) Experience with priapism. J Urol 72: 114

13. Honorio TB, Janet BL, Andranik O (1983) Ketamine treatment of penile erection in the operating room. Anaesth analg 62(4): 457-458.

14. Shantha TR (1989) Intraoperative management of penile erection by using terbutalin. Anaesthesiology 70(4): 707-709.

15. McNicholas TA, Thomson K, Rogers HS, Blandy JP (1989) Pharmacological management of erection during transurethral surgery. Br J Urol 64(4): 435-436.

16. Lawani J, Aken Ova Y, Shittu OB (1999) Priapism: An appraisal of surgical treatment. Afr J Med Med Sci 28(1-2): 21-23. 
This work is licensed under Creative Commons Attribution 4.0 License

DOI: 10.19080/JAICM.2019.09.555761
Your next submission with Juniper Publishers will reach you the below assets

- Quality Editorial service

- Swift Peer Review

- Reprints availability

- E-prints Service

- Manuscript Podcast for convenient understanding

- Global attainment for your research

- Manuscript accessibility in different formats ( Pdf, E-pub, Full Text, Audio)

- Unceasing customer service

Track the below URL for one-step submission https://juniperpublishers.com/online-submission.php 